\title{
SPATIAL DISTRIBUTION OF PHYSIOLOGICAL QUALITY OF Joannesia princeps Vell. SEEDS ${ }^{1}$
}

\author{
Rômulo André Beltrame ${ }^{2}$, José Carlos Lopes ${ }^{3}$, Julião Soares de Souza Lima ${ }^{3}$ and Vagner Mauri Quinto ${ }^{4}$ \\ ${ }^{1}$ Received on 16.08.2013 accepted for publication on 26.06.2017. \\ ${ }^{2}$ Universidade Federal do Espírito Santo, Mestre em Ciência Florestais, Alegre, Espírito Santo - Brasil. E-mail: \\ $<$ romuloagronomia@hotmail.com>. \\ ${ }^{3}$ Universidade Federal do Espírito Santo, Departamento de Fitotecnia, Alegre, Espírito Santo - Brasil. E-mail: <jcufes@bol.com.br> \\ and <limajss@yahoo.com.br>. \\ ${ }^{4}$ Universidade Federal do Espírito Santo, Departamento de Zootecnia, Alegre, Espírito Santo - Brasil. E-mail: \\ <quintoagronomo@gmail.com>. \\ *Corresponding author.
}

\begin{abstract}
The objective of this study was to analyze the spatial distribution of the attributes that determine the physiological quality of Joannesia princeps seeds. Seeds were collected, individually from, 40 mother plants in the Horto Florestal Municipal Laerth Paiva Gama, in Alegre-ES, which constituted the georeferenced sampling mesh. For germination, the seeds tegument was cracked and was held the imbibition in gibberellic acid GA $500 \mathrm{mg} \mathrm{L}^{-1}$ for $24 \mathrm{~h}$ in environmental chamber with temperature adjusted to $30^{\circ} \mathrm{C}$. The seeds were sown in plastic bags of $\pm 600 \mathrm{~cm}^{3}$ containing soil+sand+manure in the proportion of $1: 1: 1$. On the $65^{\text {th }}$ day after sowing, the following variables were analised: emergence (E), emergence speed index (IVE), root length (CR), diameter of base (DC), shoot length of the aerial part (CPA), fresh mass of the root system (MFSR), fresh mass of the aerial part (MFPA), dry mass of the root system (MSSR) and dry mass of the aerial part (MSPA). Data were subjected to descriptive statistics, geostatistics and kriging. With the exception of CPA and MFSR, it was found spatial dependence for the other studied variables: E, IVE, CR, DC, MFPA, MSSR e MSPA; varying of 14,0 a $47,5 \mathrm{~m}$, so that the lowest range for the CR and longer range and degree of spatial dependence for the IVE. The analysis of the spatial distribution of the physiological quality of seeds of J. princeps can be used as a tool to define the sampling region of seeds with high and low vigor.
\end{abstract}

Keywords: Cutieira; Physiological potential; Geoestatistics.

\section{DISTRIBUIÇÃO ESPACIAL DA QUALIDADE FISIOLÓGICA DE SEMENTES DE Joannesia princeps Vell.}

RESUMO - Objetivou-se analisar a distribuição espacial dos atributos que determinam a qualidade fisiológica de sementes de Joannesia princeps. As sementes foram coletadas, individualmente, de 40 plantas matrizes no Horto Florestal Municipal Laerth Paiva Gama, em Alegre-ES, que constituíram a malha amostral georreferenciada. Para a germinação, as sementes tiveram o tegumento trincado e foi realizada a embebição em solução de ácido giberélico $G A_{3} 500 \mathrm{mg} \mathrm{L}^{-1}$ durante $24 \mathrm{~h} \mathrm{em} \mathrm{câmara} \mathrm{tipo} \mathrm{BOD} \mathrm{a} 30^{\circ} \mathrm{C}$. A semeadura foi realizada em sacos plásticos de $\pm 600 \mathrm{~cm}^{3}$ contendo terra + areia + esterco na proporção de 1:1:1. No $65^{\circ}$ dia após a semeadura foram avaliadas as seguintes variáveis: emergência (E), indice de velocidade de emergência (IVE), comprimento da raiz (CR), diâmetro do coleto (DC), comprimento da parte aérea (CPA), massa fresca do sistema radicular (MFSR), massa fresca da parte aérea (MFPA), massa seca do sistema radicular (MSSR) e massa seca da parte aérea (MSPA). Os dados foram submetidos à análise estatística descritiva, geoestatística e interpolação por krigagem. Com exceção do CPA e da MFSR, verificou-se dependencia espacial para as demais variáveis estudadas: E, IVE, CR, DC, MFSR, MFPA, MSSR e MSPA; com alcance variando de 14,0 a 47,5 m, sendo o menor alcance obtido para o CR e o maior alcance e grau de dependência espacial para o IVE. A análise da distribuição espacial da qualidade fisiológica de sementes de J. princeps pode ser utilizada como uma ferramenta para definição da região de amostragem de sementes com alto e baixo vigor.

Palavras-chave: Cutieira; Potencial fisiológico; Geoestatítica. 


\section{INTRODUCTION}

A growing global demand for natural resources due to economic expansion has reduced native forests to small fragments, promoting ecological imbalance.

In this context, recovering degraded ecosystems and restoring them to their original state, through plant succession, is one of the greatest challenges in the present time. Additionally, throughout the process of implantation, revitalization and forest formation, nurserymen should use methods and techniques that focus on the seedlings quality improvement (Caldeira et al., 2012).

Growing plants from seeds is one of the most used methods of propagating species when it comes to the production of seedlings and the establishment of sowing areas. In addition, generating information about the physiological potential of seeds becomes substantial, since this practice can speed up the secondary succession processes and, consequently, reduce the vegetation formation time (Duboc, 2005). As reported by Popinigis (1985), the physiological quality of seeds considers its physical, genetic, physiological and health characteristics, which are responsible for the seeds ability to originate highly productive seedlings.

Joannesia princeps Vell. known as cutieira, boleira and andá-assu, is in Euphorbiaceae family. It is an endemic tree species of Brazil, spread in the North, Northeast and Southeast regions, mainly in the Amazon, Caatinga and Atlantic Forest (Cordeiro et al., 2013). Its seeds contain around $37 \%$ of oil, which is useful for industrial and medicinal purposes (Silva and Lemos, 2002). This oil has purgative properties and it is able to replace linseed oil in paintings (Sousa et al., 2007). According to Santos et al. (2009) the oil that is extracted from the arara nut-tree seeds might be an alternative for the production of biodiesel, therefore, it is a renewable energy source and entirely ecologically viable.

As stated by Amaral et al. (2013), spatial conditioning of natural phenomena often occurs along a variation between neighbors. This indicates that the variations do not occur in a random way, which means that these variations highlight some degree of spatial dependence. The geostatistical analyzes are based on the theory of regionalized variables (Isaaks and Srivastava, 1989). They are executed by the semivariogram adjustment and work in function of the degree of spatial dependence (DSD) presented by the variable of interest (Sousa et al., 2004). Thus, these analyses allow the identification of regions with higher physiological potential seed lots.

As a result of these facts, the aim of this work was to verify if there is any degree of spatial dependence when considering the physiological quality of J.princeps seeds. Also, we focused on analyzing and representing the spatial variability of these variables through thematic maps. We used geostatistics, specifically the ordinary kriging method, to estimate what occurs in non-sampled sites within the studied area.

\section{MATERIALAND METHODS}

The collection of $J$. princeps seeds happened at a protected area named Laerth Paiva Gama, in Alegre - Espírito Santo, located at coordinates $20^{\circ} 46^{\prime} 04.41$ "S and $41^{\circ} 32$ ' 59.59 " W.

In this area, we built a mesh of 40 sample points: in each point there was a mother plant, from which fruits were collected so the seeds could be extracted. The topographic survey was performed with a high precision geodesic GPS and a total station. The fruits were collected immediately after physiological maturation. Then, they were allowed to dry at room temperature and also in an oven with air circulation set at $30^{\circ} \mathrm{C}$ until dehiscence started (Brasil, 2009). The seeds were manually extracted using a lathe.

In the Seed Analysis Laboratory of the Plant Production Department of the Agricultural Sciences Center of the Federal University of Espírito Santo (CCAUFES), the seeds had their tegument cracked and were submitted to imbibition for 24 hours. GA level was (500 $\mathrm{mg} \mathrm{L}^{-1}$ ). The imbibition was performed in B.O.D. incubators. The temperature was set to $30^{\circ} \mathrm{C}$, according to the methodology proposed by Beltrame et al. (2014). Subsequently, in a greenhouse, we performed an emergence test with the sowing of one seed per black polyethylene bag, containing approximately $600 \mathrm{~cm}^{3}$ of substrate composed of soil+sand+chicken manure in a proportion of $1: 1: 1$, respectively. The chemical analysis of the substrate is shown in Table 1 . The experiment was conducted in a completely randomized design with four replications of 25 seeds.

Watering was performed whenever the substrate moisture had less than $80 \%$ of the field capacity, which was previously determined in the laboratory. The number of emerged seeds was verified daily until it would become 
Table 1 - Chemical analysis of the substrate.

Tabela 1 - Análise química do substrato.

\begin{tabular}{|c|c|c|c|c|c|c|c|c|c|c|c|c|}
\hline$\overline{\mathrm{pH}}$ & $\mathrm{P}$ & $\mathrm{K}$ & $\mathrm{Na}$ & $\mathrm{Ca}$ & $\mathrm{Mg}$ & Al & $\mathrm{H}+\mathrm{Al}$ & SB & $\mathrm{t}$ & $\mathrm{T}$ & $\mathrm{V}$ & $\mathrm{m}$ \\
\hline $\mathrm{H}_{2} \mathrm{O}$ & & $\mathrm{mg} \mathrm{dm}^{-3}$ & & & $\mathrm{cmo}$ & $\mathrm{lm}^{-3}$ & & & $\mathrm{cmol}_{\mathrm{c}}$ & & & \\
\hline 6.05 & 7.27 & 175 & 4.0 & 1.55 & 0.8 & 0.0 & 0.83 & 2.81 & $2.81^{\mathrm{c}}$ & 3.64 & 77.31 & 0.0 \\
\hline
\end{tabular}

Legend: $\mathrm{t}=\mathrm{CTC}_{\text {effective }} ; \mathrm{T}=\mathrm{CTC}_{\mathrm{pH} 7} ; \mathrm{V}=$ Saturation by bases (\%); and $\mathrm{m}=$ Percent saturation by Al.

constant. That occurred on the 21 st day after sowing. Thus, the emergence speed index (ESI) was calculated, according to Maguirre (1962): $\mathrm{ESI}=\Sigma\left(N_{1}+N_{2} \ldots N_{l} /\right.$ $\left.D_{1}+D_{2} \ldots D_{I}\right)$, in which $N_{1}+N_{2} \ldots N_{I}$ is the number of seeds that emerged on the first time they were counted, second time ... last time, respectively; $D_{1}+D_{2} \ldots D_{i}$ is the number of days in the first time they were counted, second time ... last time, respectively. On the 65 th day after sowing we evaluated: root length (RL), shoot diameter (SD), aerial part length (APL), aerial part fresh and dry matter (APFM and APDM) and root fresh and dry matter (RFM e RDM) of normal seedlings (Brasil, 2009). Root length and aerial part length were measured using a millimeter ruler. Shoot diameter was measured with a digital caliper. To evaluate the dry mass, the seedlings were placed in Kraft paper bags and kept in a forced air circulation oven at $80^{\circ} \mathrm{C}$ for 72 hours. Aerial part fresh and dry matter and root fresh and dry matter were determined in a scale with an accuracy of $0.0001 \mathrm{~g}$.

Geostatistical analysis was performed, considering the aforementioned attributes that characterize the seeds physiological quality, to verify the degree of spatial dependence. David's intrinsic stationarity hypothesis (1977) was assumed. Subsequently, the semivariance of each variable under study was calculated according to equation 1, which enabled the elaboration of semivariograms (Lima et al., 2009).

$$
\hat{\gamma}(h)=\frac{1}{2 N(h)} \sum_{i=1}^{N(h)}[Z(x i)-Z(x i+h)]^{2}
$$

$\hat{\gamma}(h)$ is the semivariance, $Z(x i)-Z(x i+h)$ are the pairs of measured values separated by a vector " $h$ ", $N(h)$ is the number of pairs of values separated by a direction vector " $h$ ", which informs the values as a function of distance, $x i$ is a spatial position of the " $Z$ ' variable being studied.

Semivariogram modeling and its validation were performed according to the variation of the data. The criteria for fitting and selecting the best model (linear, spherical, exponential or Gaussian) were: the coefficient of determination $\left(\mathrm{R}^{2}\right)$, the sum of squared residuals (SSR) and the cross-validation using the correlation coefficient (observed values versus estimated values).

The semivariogram defined the following parameters: nugget effect $\left(\mathrm{C}_{0}\right)$, which corresponds to the intersection value in the semivariance axis; range $\left(\mathrm{C}_{0}+\mathrm{C}\right)$, approximately equal to the value of the data variance; sill (S), which is the value that the semivariogram model attains at the range and the spatial dependence distance between the samples, according to Vieira et al. (1983), and the degree of spatial dependence (DSD). The degree of spatial dependence (DSD) was calculated by $\left[C_{0} /\right.$ $\left.\left(C_{0}+C\right)\right] 100$, according to criteria determined by Cambardella et al. (1994), which establishes that spatial dependence is strong if (DSD $<25 \%)$; moderate if $(25 \%$ $\leq \mathrm{DSD} \leq 75 \%$ ); and weak if (DSD $>75 \%$ ). For the attributes that showed proven spatial dependence, the interpolation was performed by ordinary kriging, so the variables values in non-sampled locations with minimal variance for the construction of the thematic maps could be estimated.

The descriptive statistical analysis was obtained with the help of Statistica software and the data were submitted to Shapiro-Wilk test and to an analysis of variance (ANOVA). Geostatistical analyses and interpolation methods were performed in GS software ${ }^{+}$ (Robertson, 1998) and the images were processed in Arc Gis software 10.0.

\section{RESULTS}

The descriptive statistical analysis of the data that characterized the physiological quality of Joannesia princeps is show in in Table 2. Emergence (E), emergence speed index (ESI), root length (RL), shoot diameter (SD), aerial part length (APL), root system fresh matter (RSFM), aerial part fresh matter (APFM), root system dry matter (RSDM) and aerial part dry matter (APDM) were the variables taken into consideration.

Revista Árvore. 2017;41(4):e410410 
Table 2 -Descriptive statistics for the studied variables of Joannesia princeps.

Tabela 2-Estatística descritiva das variáveis estudadas de Joannesia princeps.

\begin{tabular}{|c|c|c|c|c|c|c|c|c|}
\hline \multirow{2}{*}{ Variables } & \multicolumn{8}{|c|}{ Principais Estatísticas } \\
\hline & Mean & $\mathrm{s}$ & $\mathrm{s}^{2}$ & Minimum & Maximum & $\mathrm{CV}(\%)$ & Cs & $\mathrm{Ck}$ \\
\hline$E$ & 70.6 & 10.74 & 115.32 & 49.0 & 91.0 & 15.21 & -0.22 & -0.85 \\
\hline IVE & 11.21 & 1.48 & 2.19 & 7.6 & 13.55 & 13.20 & -0.27 & -0.15 \\
\hline $\mathrm{CR}$ & 12.55 & 1.16 & 1.35 & 9.65 & 15.10 & 9.24 & -0.07 & 0.23 \\
\hline $\mathrm{DC}$ & 0.92 & 0.05 & 0.0025 & 0.85 & 1.02 & 5.43 & 0.21 & -1.11 \\
\hline CPA & 67.67 & 4.06 & 16.46 & 56.65 & 74.49 & 5.99 & -0.81 & 0.56 \\
\hline MFSR & 3.55 & 4.50 & 20.23 & 1.51 & 23.17 & 126.7 & 3.48 & 11.51 \\
\hline MFPA & 44.81 & 6.35 & 40.31 & 30.49 & 55.85 & 14.17 & -0.29 & -0.17 \\
\hline MSSR & 0.327 & 0.07 & 0.0055 & 0.12 & 0.48 & 21.40 & -0.32 & 0.63 \\
\hline MSPA & 5.10 & 1.00 & 1.00 & 2.07 & 6.80 & 19.6 & -0.84 & 1.33 \\
\hline
\end{tabular}

According to Table 2, the variables that obtained the lowest values of standard deviation were ESI, RL, SD, RSDM and APDM (1.48, 1.16, 0.05, 0.07, and 1.0, respectively). APL, RSFM and APFM assumed medium values. E presented the highest standard deviation (10.74) (Table 2), which indicates a high dispersion of the data collected in relation to the mean.

When regarding the coefficient of variation (CV), which evaluates the dispersion of the data around the mean (Landim, 2003), in Table 2, we took the classification proposed by Warrick and Nielsen (1980) in consideration: low values are those that are $<12 \%$; medium values are $12 \% \leq \mathrm{CV} \leq 60 \%$ and high values are $\mathrm{CV}>60 \%$. Given this, we observed that RL, SD, APL variables were within the low $\mathrm{CV}$ range, while the variables $\mathrm{E}$, ESI, APFM, RSDM and APDM were within the medium $\mathrm{CV}$ range. However, for RSFM variable, $\mathrm{CV}$ is classified as high.

Furthermore, when we deem the asymmetry coefficient (Cs), which corresponds to a distance from the variable in relation to a central value, it can be noticed that the distribution was only positive for the RSFM variable (3.48) (Table 2), due to the fact that the mean was greater than the median. That characterizes an asymmetric distribution to the right. Then again, for the other analyzed variables, Cs assumed negative values, which characterizes an asymmetric distribution to the left. That indicates a higher concentration of data above the mean. When analyzing the kurtosis coefficients (Ck) (Table 2), it can be observed that the variables E, ESI, SD and APFM indicate a platykurtic distribution, while RL, APL, RSFM, RSDM and APDM show a leptokurtic distribution.

The results of $J$. princeps spatial analysis, according to geostatistical methodology, are shown in Table 3.
Variables E, RL, APFM and APDM were adjusted to the spherical model; ESI, SD and RSDM to the Gaussian model; APL and RSFM presented pure nugget effect. Variables E, RL, SD, APFM and APDM reached similar ranges of spatial dependence: $20.0 ; 14.0 ; 23.0 ; 16.0$ and $29.0 \mathrm{~m}$ (Table 3 ); respectively. That indicates a pattern. Correspondingly, ESI and RSDM also have similar spatial patterns, with ranges of 47.5 and 47.0 $\mathrm{m}$, respectively. Gaussian model was used (Table 3 ).

The semivariograms for the variables (E, ESI, RL, SD, APL, RSFM, APFM, RSDM and APDM) that characterize the physiological quality of $J$. princeps are shown in Figure 1.

The degree of spatial dependence (DSD) was strong for RL, SD and APFM variables $(6.1,17.2$ and 0.1 , respectively) (Table 3 ) and moderate for E, ESI, RSDM and APDM. The coefficient of multiple determination $\left(\mathrm{R}^{2}\right)$ varied from $58.5 \%$ (E) to $98.2 \%$ (APFM), (Table 3).

The definition of semivariograms models and parameters made it possible for us to perform the interpolation using ordinary kriging in order to create thematic maps of E, ESI, RL, SD, APL, APFM, RSDM and APDM variables (Figure 2).

It was observed in Figure 2A that the highest values of emergence were obtained in the eastern region (between 7701430 and $7701460 \mathrm{~m}$ latitudes) of the study area: they went from 81 to $91 \%$. The lowest $\mathrm{E}$ values are in the West: from 49 to $60 \%$. Therefore, seedlings emergence shows a pattern of spatial dependence in relation to western and eastern regions. The lowest ESI values are found in the upper North region of the study area. Values range between 5.75 and 8.00 (Figure 2B). However, ESI highest proportion in the 
Table 3 - Parameters and models of semivariograms scaled adjusted for the studied variables that characterize the physiological quality of the seeds of Joannesia princeps.

Tabela 3 - Parâmetros e modelos dos semivariogramas escalonados ajustados para as variáveis que caracterizam a qualidade fisiológica das sementes de Joannesia princeps.

\begin{tabular}{|c|c|c|c|c|c|c|c|}
\hline \multirow{2}{*}{ Variables } & \multicolumn{7}{|c|}{ Parameters and models of semivariograms } \\
\hline & Model & $\mathrm{C}_{0}$ & $\mathrm{C}_{0}+\mathrm{C}$ & $\mathrm{a}(\mathrm{m})$ & $\mathrm{R}^{2}(\%)$ & GDE (\%) & SQR \\
\hline $\mathrm{E}$ & Spherical & 0.5 & 1.1 & 22.0 & 58.5 & 44.5 & 1551.0 \\
\hline IVE & Gaussian & 0.6 & 1.2 & 47.5 & 78.5 & 50.0 & 1.79 \\
\hline $\mathrm{CR}$ & Spherical & 0.1 & 1.3 & 14.0 & 59.0 & 6.1 & 0.46 \\
\hline $\mathrm{DC}$ & Gaussian & 0.3 & 1.6 & 23.0 & 79.6 & 17.2 & 0.0 \\
\hline CPA & Pure nugget effect & 1.0 & 1.0 & - & - & - & - \\
\hline MFSR & Pure nugget effect & 1.0 & 1.0 & - & - & - & - \\
\hline MFPA & Spherical & 0.002 & 1.5 & 16.0 & 98.2 & 0.1 & 54.6 \\
\hline MSSR & Gaussian & 0.6 & 1.3 & 47.0 & 83.4 & 43.4 & 0.0 \\
\hline MSPA & Spherical & 0.3 & 1.2 & 29.0 & 60.8 & 26.2 & 0.24 \\
\hline
\end{tabular}

Legend: $\mathrm{E}=$ emergency $(\%) ; \mathrm{IVE}=$ speed index emergency; $\mathrm{CR}=$ root length $(\mathrm{cm}) ; \mathrm{DC}=$ diameter of the base $(\mathrm{mm}) ; \mathrm{CPA}=$ shoot length

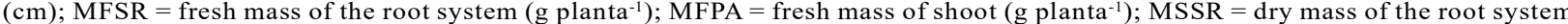
$\left(\mathrm{g}\right.$ planta $\left.{ }^{-1}\right) ; \mathrm{MSPA}=$ dry mass of shoot $\left(\mathrm{g}\right.$ planta $\left.{ }^{-1}\right) ; \mathrm{EPP}=$ pure nugget effect; $\mathrm{C}_{0}=$ nugget effect; $\mathrm{C}_{0}+\mathrm{C}=\mathrm{baseline} ; \mathrm{a}=$ range; $\mathrm{R}^{2}=\mathrm{coefficient}$ of determination of the semivariogram; GDE = degree of spatial dependence $\left(\mathrm{C}_{0} / \mathrm{C}_{0}+\mathrm{C}\right)$; and $\mathrm{SQR}=$ sum of squares of residuals.

map shows values between 10.01 and 12.00 (Figure 2B). The highest values are distributed irregularly, concentrated at some points in the area. In spite of that, it was still possible to observe a spatial dependence pattern regarding ESI growth from the North to the South of the study area.

As displayed in Figure 2C, the mean RL value showed spatial dependence in which values between 12.01 and $14.00 \mathrm{~cm}$ were predominant. They were distributed throughout the whole map area. Although the highest concentration of points with the highest CR values were in the central part of the studied area. Figure 2D exhibits SD spatial distribution: values between 0.91 and $0.95 \mathrm{~mm}$ may be found everywhere in the study area. Conversely, values between 0.96 and $1.00 \mathrm{~mm}$ are found in the central and eastern region of the map.

Mean RSDM values are in almost all over the area: 0.34 and $0.44 \mathrm{~g}$ (Figure 2E). At the same time, RSDM values between 0.23 and $0.33 \mathrm{~g}$ are clustered in the central area (Figure 2E). Still, in upper East, RSDM values range from 0.45 to $0.55 \mathrm{~g}$ (Figure $2 \mathrm{E}$ ).

Aerial part fresh matter (Figure $2 \mathrm{~F}$ ) values go from 40.01 to $50.00 \mathrm{~g}$ throughout the entire study area. However, APFM values ranging from 50.01 to $60.00 \mathrm{~g}$ were obtained at isolated points in the North, Northeast, East and South of the studied area. APDM values are between 4.51 and $6.00 \mathrm{~g}$ (Figure $2 \mathrm{G}$ ) in almost the whole map. In the Center-West values are between 3.01 and $4.50 \mathrm{~g}$ (Figure 2G). In the southern region of the map, there is a higher concentration of APDM values that go from
6.01 to $7.50 \mathrm{~g}$ (Figure $2 \mathrm{G}$ ). These last values may be found in isolated points in East and Upper East.

\section{DISCUSSIONS}

The descriptive statistical analysis confirmed normal data distribution for most of the variables that characterize the physiological quality of Joannesia princepsseeds. Normal data distribution was confirmed by the fact that the mean and median values are close. Also, asymmetry $\left(\mathrm{C}_{\mathrm{s}}\right)$ and kurtosis $\left(\mathrm{K}_{\mathrm{w}}\right)$ coefficients approach zero. That all happens for all variables, except for root system fresh matter (RSFM). These results were confirmed by Shapiro-Wilk test.

The magnitude of the coefficient of variation $(\mathrm{CV})$ might elucidate the variability of an attribute. In general, according to the classification proposed by Warrick and Nielsen (1980), the $\mathrm{CV}_{\mathrm{s}}$ that were obtained in this study were classified as low, medium and high. On the other hand, the CV is considered high only for RSFM variable, which indicates low data dispersion for all the other studied variables. E, ESI, SD and APFM presented platykurtic distribution, while RL, APL, RSFM, RSDM and APDM exhibited leptokurtic distribution with positive $\mathrm{K}_{\mathrm{c}}$. That indicates data concentration around the mean.

When analyzing Table 3, it was observed that $33.33 \%$ of the variables adjusted to the Gaussian model and $44.44 \%$ to the spherical model. Approximately $22.23 \%$ of the variables did not adjust to any model in consonance with the sampling mesh we adopted: they presented pure nugget effect. APL and RSFM showed no spatial 

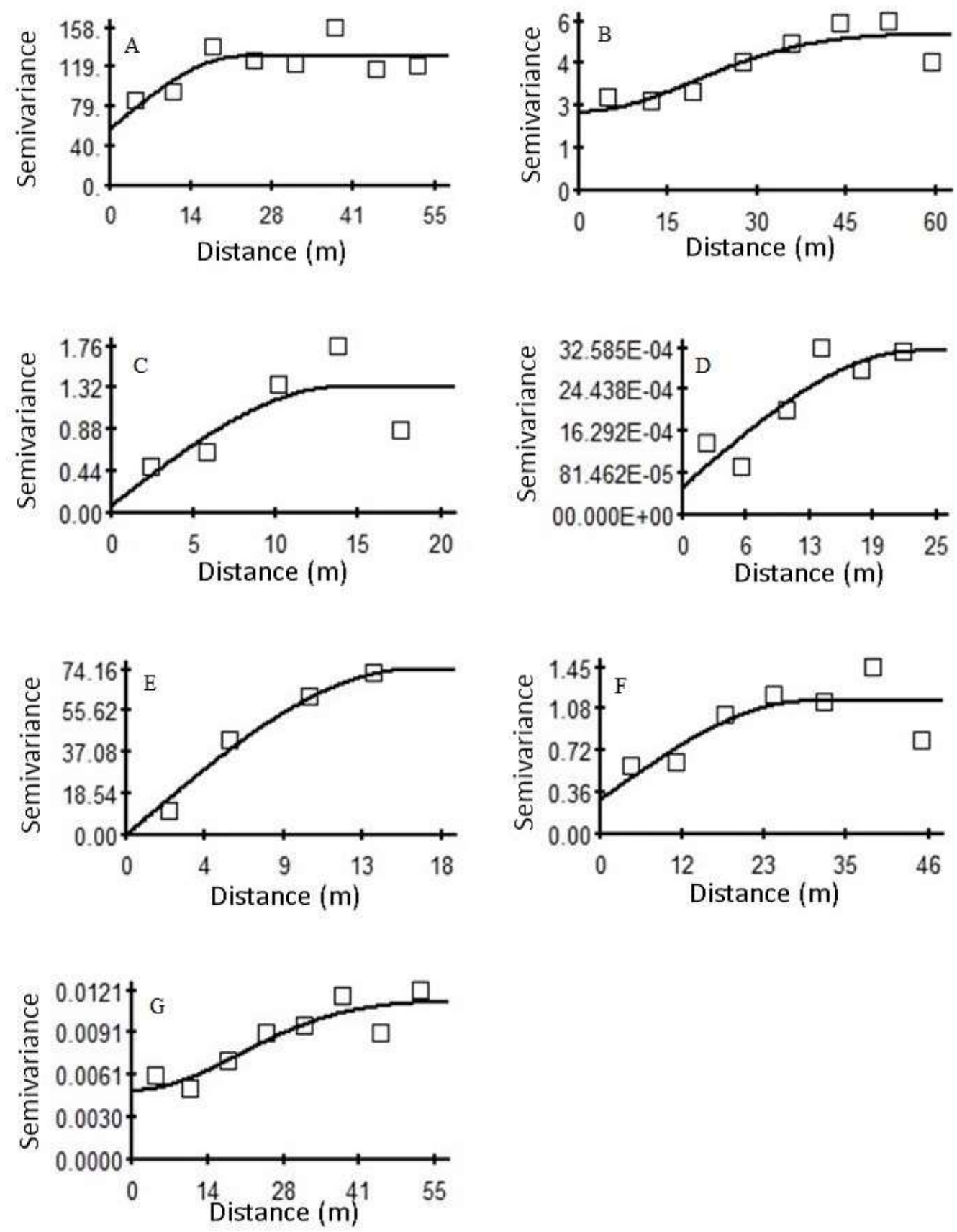

Figure 1 - Semivariograms for the variables that characterize the physiological quality of the seeds of Joannesia princeps. A) emergence. B) speed index emergence. C) root length. D) collar diameter. E) fresh weight of shoot. F) shoot dry mass and $\mathrm{G}$ ) root dry mass. The $\mathrm{x}$ axis corresponds the distance. in meters. and the $\mathrm{y}$-axis are the values of semi variances $\left(\%^{2}\right)$.

Figura 1 - Semivariogramas para as variáveis que caracterizam a qualidade fisiológica das sementes de Joannesia princeps. A) emergência, $B$ ) índice de velocidade de emergência, C) comprimento da raiz, D) diâmetro do coleto, E) massa fresca da parte aérea, $F$ ) massa seca da parte aérea e $G$ ) massa seca do sistema radicular. $O$ eixo $x$ corresponde a distância, em metros, e o eixo y os valores das semivarâncias $\left(\%{ }^{2}\right)$. 


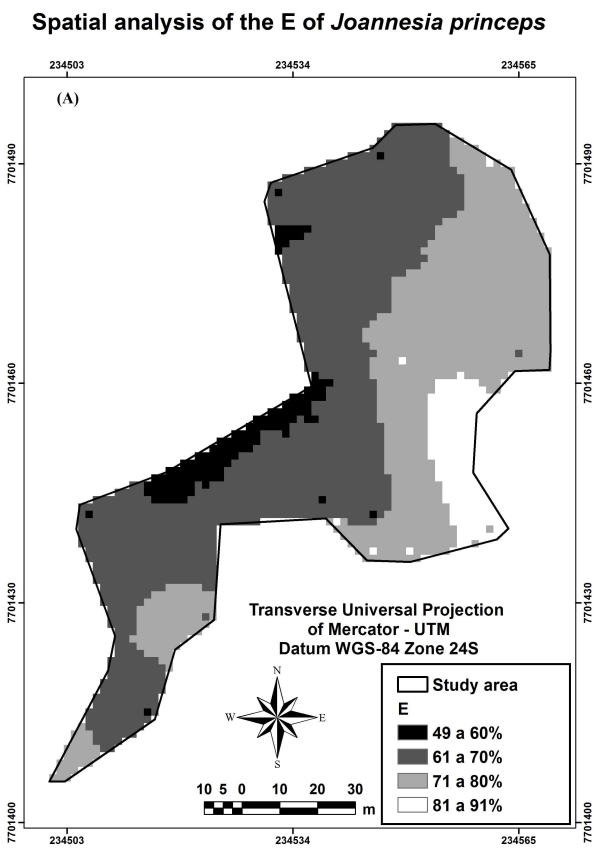

Spatial analysis of the IVE of Joannesia princeps

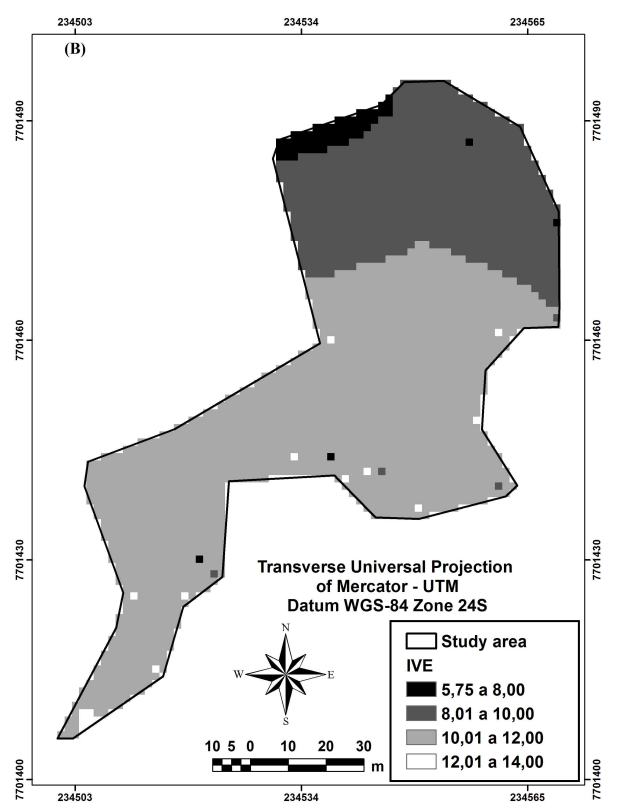

Spatial analysis of the CR of Joannesia princeps 234565

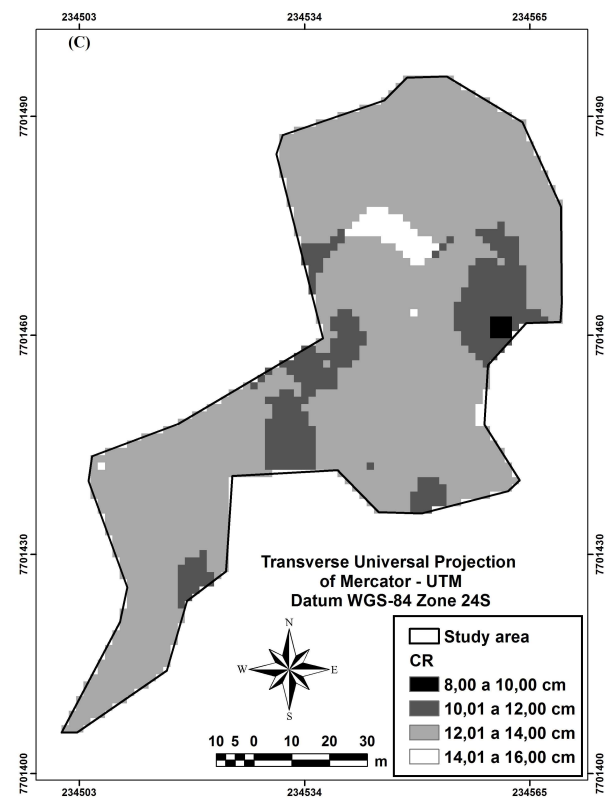

Spatial analysis of the DC of Joannesia princeps

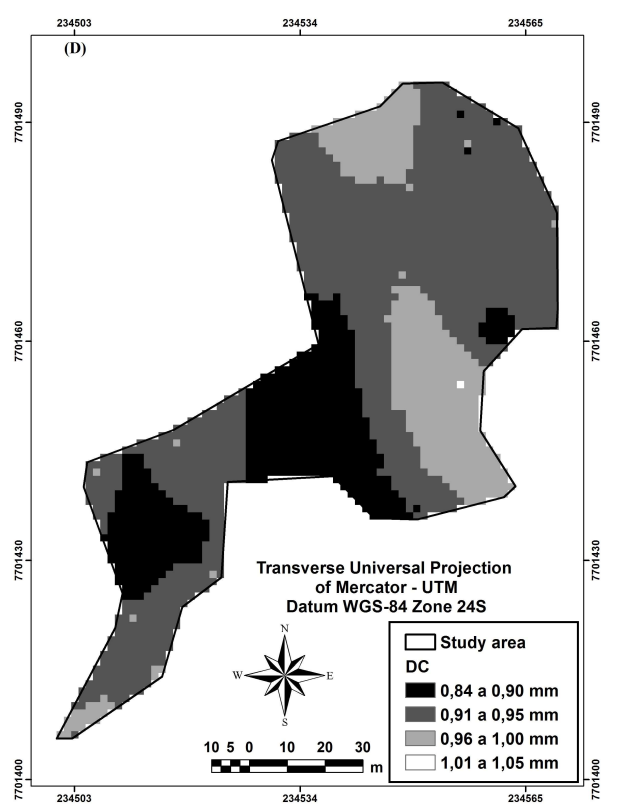

Continue...

Continua.. 
Figure 2 ...

Figura 2 ...

Spatial analysis of the MSSR of Joannesia princeps

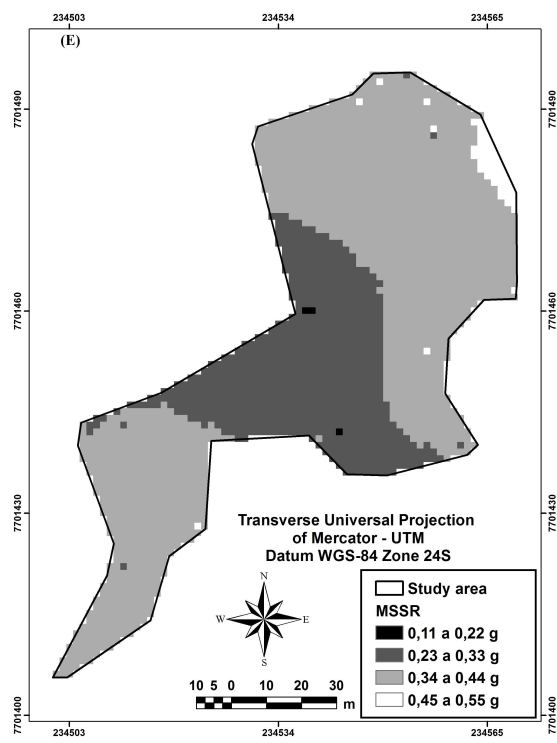

Spatial analysis of the MSPA of Joannesia princeps

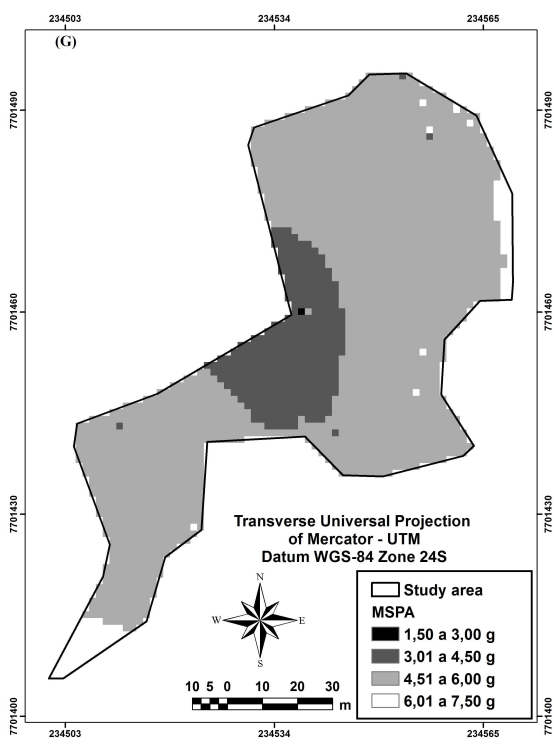

Spatial analysis of the MFPA of Joannesia princeps

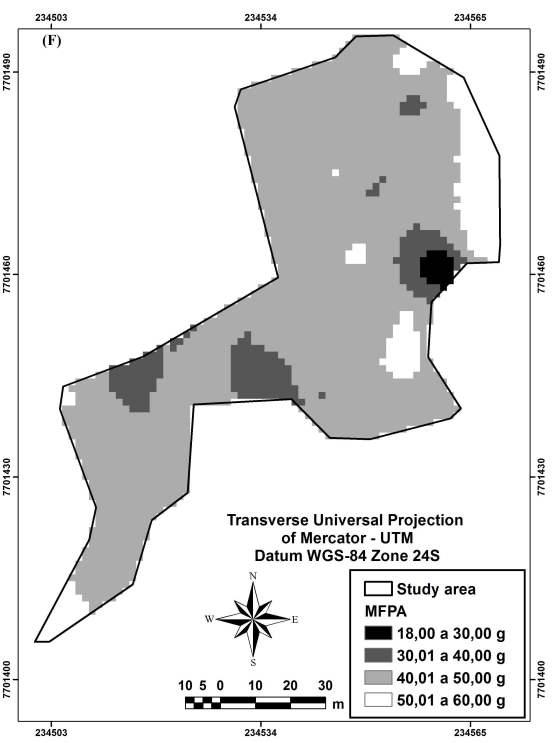

Figure 2 - Thematic map of the variables that characterize the physiological quality of the seeds of Joannesia princeps: A) emergency $=$ E. B) speed index emergency $=$ IVE. C) root length $=$ R. D) collar diameter $=$ DC. E) root dry mass $=$ MSSR. F) fresh weight of shoot = MFPA and G) shoot dry mass = MSPA.

Figura 2 - Mapas temáticos das variáveis que caracterizam a qualidade fisiológica das sementes de Joannesia princeps: A) emergência $=E, B$ ) indice de velocidade de emergência $=I V E, C)$ comprimento da raiz $=C R, D)$ diametro do coleto $=D C, E$ ) massa seca do sistema radicular $=M S S R, F)$ massa fresca da parte aérea $=$ MFPA e $G)$ massa seca da parte aérea $=$ MSPA. 
dependence for distances greater than the lowest sampling, suggesting that the samples may be independent. When studying the physiological quality of Coffea arabica L. seeds, Lopes et al. (2014) also used spherical and Gaussian models, which confirm their importance for the spatial distribution of plant parameters. Ferraz et al. (2017) also adopted the spherical model to describe the spatial distribution of some specific attributes, such as C. arabica. yield, maturation index and crown diameter.

We could verify $\mathrm{C}_{0}$ values for $77.78 \%$ of the studied variables (E, ESI, RL, SD, APFM, APDM and RSDM). Besides indicating spatial dependence, this fact demonstrates that the sampling performed in this work was effective in determining the variability component within the studied area. Vieira et al. (2009) reported that $\mathrm{C}_{0}$ is the explained variance due to errors in the distribution or variations of the variables that can not be detected with the sampling.

Variables E, RL, SD, APFM and APDM display a similar spatial pattern: their values for spatial dependence go from 14 to $29 \mathrm{~m}$. As well as ESI and RSDM, with 47.5 and $47.0 \mathrm{~m}$ ranges, respectively (Table 3 ). The definition of the spatial dependence values allows us to distinguish correlated samples. According to Lima et al. (2014), samples that were collected from a distance that is smaller than their range are correlated to each other. That permits the interpolation for spaces that are smaller than the ones adopted in the sampling. The obtained spatial dependence ranges directly influence the estimates quality, since they determine the number of neighbors used in the interpolation. Thus, estimates made with interpolation by ordinary kriging, using larger range values, tend to be more reliable, since they work with larger numbers of neighbors. In that way, these estimates are able to present maps that better represent reality (Cora et al., 2004).

The degree of spatial dependence (DSD), classified as strong for RL, SD and APFM (DSD $<25 \%$ ), moderate for E, ESI, RSDM and APDM $(25 \% \leq \mathrm{GDE} \leq 75 \%)$, according to Cambardella et al. (1994), suggests: greater continuity of the phenomenon, lower variance of the estimate and greater reliability on the estimated value (Lima et al., 2006). That means that the correlations between the values observed and estimated by the cross validation, using ordinary krigring, are significant. On the other hand, as reported by Kitamura et al. (2007), a low correlation or a low DSD between any two variables do not invalidate the hypothesis of spatial correlation between them. Additionally, because the multiple determination coefficients $\left(\mathrm{R}^{2}\right)$ presented values higher than $50 \%$, with a minimum of $58.5 \%$ (E) and a maximum of $98.2 \%$ (APFM) the estimated values were obtained with a greater reliability by the ordinary kriging interpolation method, in consonance with Azevedo (2004).

The construction of E, ESI, RL, SD, APL, APFM, RSDM and APDM thematic maps (Figure 2) using ordinary kriging can contribute to two points: an understanding of the spatial distribution pattern of $J$. princeps seeds physiological quality, and the distinction between regions of high vigor and low vigor, when considering seed collections. The last point is mentioned by Lopes et al. (2014) when analyzing $C$. arabica seeds. Seed vigor can be understood as the energy that the seed has in order to perform the germination process tasks (Carvalho and Nakagawa, 2012).

These variables generate valuable information for the formation of a stand with normal and vigorous seedlings. They are a sign of better physiological seed quality (Marcos Filho, 2005). Silva et al. (2010) reported that knowing the spatial variability of soil and plant properties may have positive effects on crop yield, since small changes in management may generate different responses.

Information about the spatial distribution of seed vigor may enable the development of strategies for $J$. princeps seed collection in regions where there is a higher concentration of mother-plants, from which seeds present higher physiological quality, since there is spatial dependence for most of the studied variables.

\section{CONCLUSIONS}

There is spatial dependence for emergence, emergence speed index, root length, shoot diameter, aerial part fresh matter, root system dry matter and aerial part dry matter.

There is no spatial dependence when regarding aerial part length and root system fresh matter.

The extent of spatial dependence varies from 14.0 to $47.5 \mathrm{~m}$.

The analysis of the spatial distribution of the physiological quality of $J$. princeps may be used as 
a tool to define the regions where there are high vigor seeds and low vigor seeds.

\section{ACKNOWLEDGEMENTS}

Thanks to CAPES for granting the graduate study scholarship; and to CNPq - Edital Universal No 14/ 2011 (Case number: 475471 / 2011-3) for sponsoring the research material.

\section{REFERENCES}

Amaral LP, Ferreira RA, Lisboa GS, Longhi SJ, Watzlawick LF. Variabilidade espacial do índice de diversidade de shannon-wiener em floresta Ombrófila Mista. Scientia Forestalis. 2013;41(97):83-93.

Azevedo EC. Uso de geoestatística e recursos de geoprocessamento no diagnóstico da degradação de um solo argiloso sob pastagem no estado do Mato Grosso [tese]. 2004. Campinas: Universidade de Campinas; 2004.

Brasil. Ministério da Agricultura, Pecuária e Abastecimento. Regras para análise de sementes. Brasília: 2009.

Beltrame RA, Lopes JC, Mengarda LHG, Manhone PR, Freitas AR. Tratamentos pré-germinativos e sombreamentos na produção de mudas de cutieira. Revista Brasileira de Agroecologia. 2014;9(2):193205.

Caldeira MVW, Peroni L, Gomes DR, Delarmelina WM, Trazzi PA. Diferentes proporções de biossólido na composição de substratos para a produção de mudas de timbó (Ateleia glazioveana Baill). Scientia Forestalis. 2012;40(93):15-22.

Cambardella CA, Moorman TB, Novak JM, Parkin TB, Karlen DL, Turco RF et al. Field-scale variability of soil properties in Central Iowa Soils. Soil Science Society of America Journal. 1994;58(2):1501-11.

Carvalho NM, Nagagawa J. Sementes: ciência, tecnologia e produção. Jaboticabal: FUNEP: 2012.

Cora JE, Araujo AV, Pereira GT, Beraldo JMG. Variabilidade espacial de atributos do solo para adoção do sistema de agricultura de precisão na cultura de cana-de-açúcar. Revista Brasileira de Ciências do Solo. 28(6):1013-21.

Cordeiro I, Secco R, Cardiel JM, Steinmann V, Caruzo MBR, Riina R et al.. Euphorbiaceae in Lista de Espécies da Flora do Brasil. Rio de Janeiro: Jardim Botânico do Rio de Janeiro. 2013. [acesso em: 23 abr. 2013]. Disponível em: http:// floradobrasil.jbrj.gov.br/jabot/listaBrasil/ ConsultaPublicaUC/ConsultaPublicaUC.do.

David M. Geoestatistical ore reserve estimation. New York: Elsevier Scientífic; 1977. 364p.

Duboc E. Desenvolvimento inicial e nutrição de espécies arbóreas nativas sob fertilização, em plantios de recuperação de áreas de cerrado degradado [tese]. Botucatu: Faculdade de Ciências Agronômicas da UNESP, 2005.

Ferraz GAS, Silva FM, Oliveira MS, Custódio AAP, Ferraz PFP. Variabilidade espacial dos atributos da planta de uma lavoura cafeeira. Revista de Ciência Agronômica. 2017;48(1):81-91.

Isaaks EH, Srivastava RM. An introduction to applied geostatistics. New York: Oxford University Press; 1989. 600p.

Kitamura AE, Carvalho MP, Lima CGR. Relação entre a variabilidade espacial das frações granulométricas do solo e a produtividade do feijoeiro sob plantio direto. Revista Brasileira de Ciência do Solo. 2007;31:361-9.

Lima JSS, Bona DAO, Fiedler NC, Pereira DP. Distribuição espacial das frações granulométricas argila e Areia total em um Latossolo VermelhoAmarelo. Revista Árvore. 2014;38(3):513-21.

Lima JSS, Sattler MA, Passos RR, Oliveira PC, Souza GS. Variabilidade espacial de atributos físicos de um Argissolo Vermelho-amarelo sob pastagem e vegetação secundária em regeneração natural. Engenharia Agrícola. 2009;29(2):185-95.

Lima JSS, Silva JTO, Oliveira RB, Almeida S, Vanzo FL. Estudo da viabilidade de métodos geoestatísticos na mensuração da variabilidade espacial da dureza da madeira de Paraju (Manilkara sp.). Revista Árvore. 2006;30(4):651-7. 
Landim PMB. Análise estatística de dados geológicos. $2^{a}$.ed. São Paulo: UNESP; 2003. 253p.

Lopes JC, Trigo MFIQ, Lima JSS, Silva SA. Spatial distribution of physiological quality of Arábica coffee seeds to cultivate Catuaí. Idesia. 2014;32(2):65-74.

Maguirre JD. Speed of germination-aid in and evaluation for seedling emergence and vigour. Crop Science, 1962;2(1):176-7.

Marcos Filho J. Fisiologia de sementes de plantas cultivadas. Piracicaba: FEALQ; 2005. 495p.

Popinigis F. Fisiologia da semente. Brasília, DF: Associação Brasileira de Educação Agrícola Superior/ Ministério da Educação e Cultura; 1985. 289p.

Robertson GP. GS $\mathrm{GS}^{+}$Geostatistics for the environmental sciences-GS ${ }^{+}$user's GuGDE. Plainwell: Gamma Design Software; 1998. 152p.

Santos RB, Souza TS, Lacerda Junior V, Castro EVR. Síntese e estudo do biodiesel do óleo da cutieira (Joannesia princeps). Vitória: 2009. [acesso em: 1 set. 2011]. Disponível em: http:// pt.scribd.com/doc/22582236/Analise-de-Biodiesel.

Silva DB, Lemos BS. Plantas da área verde da Super Quadra. Brasília, DF: Embrapa - Recursos Genéticos e Biotecnologia; 2002. [acesso em: 5 set. 2011]. Disponível em: http:// www.alice.cnptia.embrapa.br/bitstream/doc/184370/ 1/liv003.pdf.

Silva SA, Lima JSS, Souza GS. Estudo da fertilidade de um Latossolo Vermelho-Amarelo húmico sob cultivo de café arábica por meio de geoestatística. Revista Ceres. 2010;57(4):560-7.

Sousa OV, Fioravante IA, Yamamoto $\mathrm{CH}$, Alves MS, Vieira GD, Araújo ALA. Propriedades biológicas das sementes de Joannesia Princeps Vellozo. Revista HU. 2007;33(1):23-7.

Sousa ZM, Marques Júnior J, Pereira TP. Variabilidade espacial de agregados e matéria orgânica em solos de relevo diferentes. Pesquisa Agropecuária Brasileira. 2004;39(5):491-9.

Vieira SR, Guedes Filho O, Chiba MK, Cantarella H. Spatial variability of soil chemical properties after coffee tree removal. Revista Brasileira de Ciência do Solo. 2009;33:1507-14.

Vieira SR, Hatfield TL, Nielsen DR et al. Geoestatistical theory and application on variability of some agronomical properties. Hilgardia. 1983;51:1-75.

Warrick AW, Nielsen DR. Spatial variability of soil physical properties in the field. In: Illel D, editor. Applications of soil physics. New York: Academic; 1980. p.319-44. 